\title{
ファジィ制御を用いた静止形無効電力補償装置
}

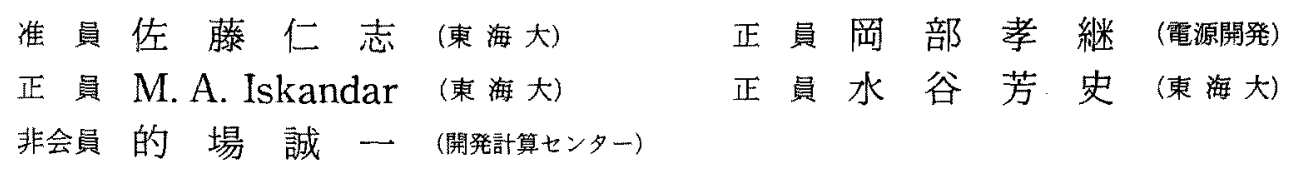

\section{Application of Fuzzy Control to Static Var Compensator}

Masashi Satoh, Associate, Marzan Aziz Iskandar, Member (Tokai University), Seiichi Matoba, Non-member (The Kaihatsu Computing Service Center Ltd.), Takatsugu Okabe, Member (Electric Power Development Co., Ltd.), Yoshibumi Mizutani, Member (Tokai University)

キーワード：ファジィ制御，静止形無効電力補償装置 (SVC), 安定化制御

現在, 電力系統は長距離, 大容量化の傾向にあり, 電力の安定供給が重要な問題となってきている。そこ で, 送電線路に静止形無効電力補償装置（SVC）を 設置することによりこの問題に対応している(1) (4)。 しかし，非線形性を考慮したSVCの制御手法につい ては,これからの研究課題で, 近年, 知識と経験に基 づく柔軟な非線形制御が期待されるファジィ制御(5) の適用が考えられる(6)。

本報告では，図1の一機無限大母線系モデルを用い て, 長距離送電線路の中間地点にSVC を設置し, 安 定化信号にファジィ制御(5)を用いる手法を提案する。

本制御方式は，図 20 安定化信号 $U_{\mathrm{svc}}$ に, 図 30 ファジィ制御操作量 $U_{f}$ を導入するもので, 系統の安 定性とともに，電圧を定常時に基準值に維持すること を目的とし，リセット回路を考慮した比例・微分形制 御である。すなおち, 図 3 の本ファジィ制御器 FUSP は SVC 設置点で, 観测が容易で, 測定時に雑 音の影響を受けにくい有効電力偏差 $\Delta P_{c}$ を観測し， 測定器, リセット回路を通して, その出力を $E_{p}(k)$ とする。そして，その変化分を $\Delta E_{p}(k)=\left\{E_{p}(k)\right.$ $-E_{p}(k-1\} / T$ とし， $E_{p}$ 学横軸， $\alpha_{1} \times \Delta E_{p}$ を綎軸に とった平面にこれらを描くと次の点 $p_{f}$ を得る。

$$
\begin{aligned}
& p_{f}(k)=D_{e}(k)\{\theta(k) \\
& \text { ただし. } D_{e}(k)=\sqrt{E_{p}(k)^{2}+\left\{\alpha_{1} \Delta E_{p}(k)\right\}^{2}}, \\
& \theta(k)=\cos ^{-1}\left\{E_{p}(k) / D_{e}(k)\right\}, \alpha_{1}: \text { 調整パラメー }
\end{aligned}
$$$$
\text { 夕, } T \text { : サンプル周期, } k: 0,1,2 \cdots
$$

$U_{f}(k)$ を決定するために，文献(6)に基づき図 4 (a), (b)に示す $\theta, D_{e}$ のメンバシップ関数を構成 ᄂ, 次式に示寸制御操作量 $U_{f}(k)$ 在算出する。

$$
U_{f}(k)=\left\{2 \mu_{N}(k)-1\right\} \mu_{C}(k) U_{m}
$$

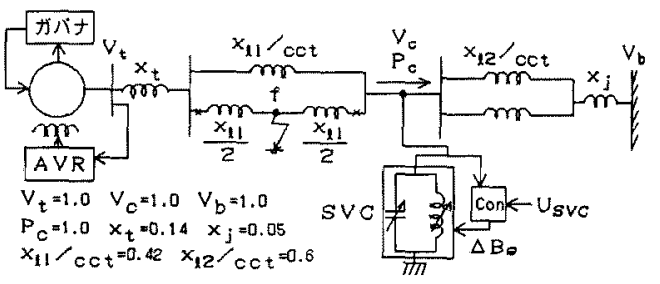

図 1 一機無限大母線系モデル

Fig. 1. One machine infinite bus system.

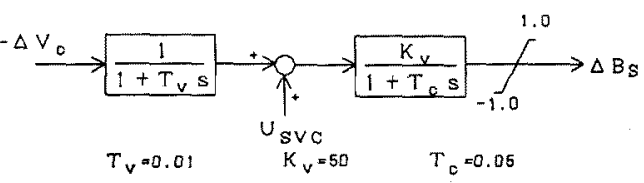

図 2 SVCの構成図

Fig. 2. Block diagram of SVC.

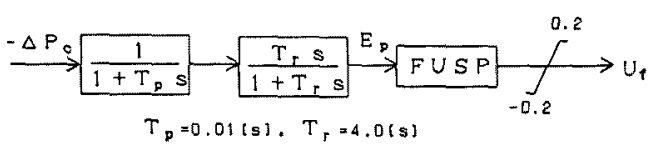

园 3 提案する制御方式

Fig. 3. Block diagram of proposed control.

ただし， $U_{m}$ : 制御操作量の最大值

そして， $U_{f}$ を $U_{\mathrm{svc}}$ として次のように用いる。

$U_{\mathrm{svc}}(k)=U_{f}(k)$

ここで,この FUSPの調整パラメータは $\alpha_{1}, \alpha_{2}, \alpha$ と なり, サンプル周期 $T$ は0.01秒としている。

本ファジィ制御器の調整パラメータを決定するため に, 次の大小外乱を用いた。

（1）図 $10 f$ 点で三相地絡故障後 0.1 秒で故障 


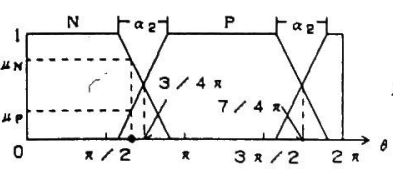

(a) $\theta$

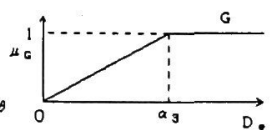

(b) $D_{e}$
図 4 メンバシップ関数

Fig. 4. Membership functions.

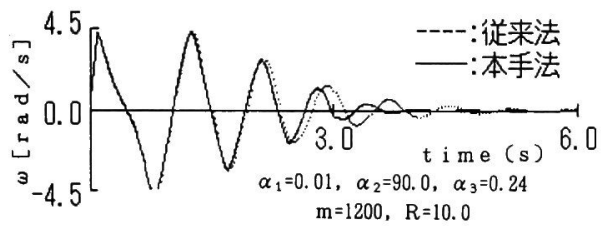

図 5 大外乱の応答

Fig. 5. Responses under large disturbance

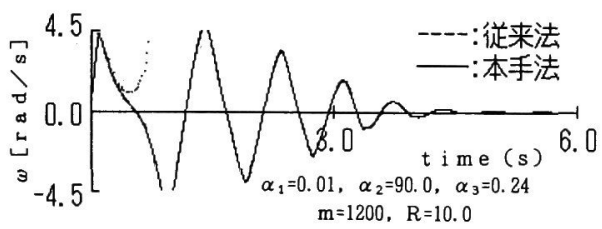

図 $6 x_{j}$ を1.3倍にした場合の大外乱の応答

Fig. 6. Responses under large disturbance for 1.3 times of $x_{j}$

回線を開放した大外乱。

（2）発電機の機械的入力が三角状に変化した小外 乱家。

そして, 制御操作量 $U_{f}$ のむだな振動を減少させる ために $\dot{U}$ を考慮した次式の評価関数 $J$ を用いて，大 外乱の $J$ を $J_{1}$ とし, 小外乱の $J$ を $J_{2}$ とし, その合計 $J_{t 0}$ が最小になるように調整パラメータを決定する。

$$
\begin{aligned}
& \left.\begin{array}{l}
J=\sum_{k=1}^{m}\left\{|\Delta \omega(k)| t_{k}+|\dot{U}|\right\} \\
J_{t 0}=J_{1}+R J_{2}
\end{array}\right\} \\
& \text { ただし， } m \text { : サンプルデー夕数, } t_{k}=k T \text {, } \\
& \dot{U}=\left\{U_{f}(k)-U_{f}(k-f)\right\} / T, R: J_{2} \text { の重み }
\end{aligned}
$$

図 5 は，大外乱が発生したときの本手法と従来法の $\Delta \omega$ の応答である。本手法は, 従来法と比較して収束 性も良く十分良好な制御効果をあげている。ただし， 従来法としては, 図 7 に示す制御器を用いた。ここ で，定常時において，SVC 設置点の電圧を基準値に 維持するという意図から比例・微分形制御とし，ゲイ ン $K_{p}, K_{d}$ は, 文献 ( 1 )の固有值法を用いて設計した。 図 6 は, 図 1 の $x_{j}$ を 1.3 倍とし, 図 5 と同じパラメ 一夕を用いたときの大外乱の応答である。従来法は不

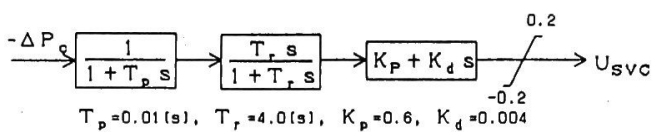

図 7 従来の制御方式

Fig. 7. Block diagram of conventional control.

安定となるが, 本手法は安定でロバスト性が高いこと がわかった。

(平成 4 年 10 月 21 日受付)

\section{文献}

(1) C. J. Wu \& Y.S. Lee: IEE Proc. 138, No. 5, 427 (1991)

(2) Chin-Hsing Cheng \& Yuan-Yih Hsu: IEEE Trans. 7, No. 2, 718 (1992)

(3) 木下: 電学論 B, 99789 (昭 54-12)

（4）大山・芹澤・関根：同上 B, 105，1009（昭 60-12）

(5) T. Hiyama, T. Sameshima : Fuzzy Sets and System, 39, p. 181 (1991) North-Holland

（6）佐藤 - M. A. Iskandar - 的場 - 岡部 - 水谷：電気学会電力技 術研資，PE-92-087 (平 4)
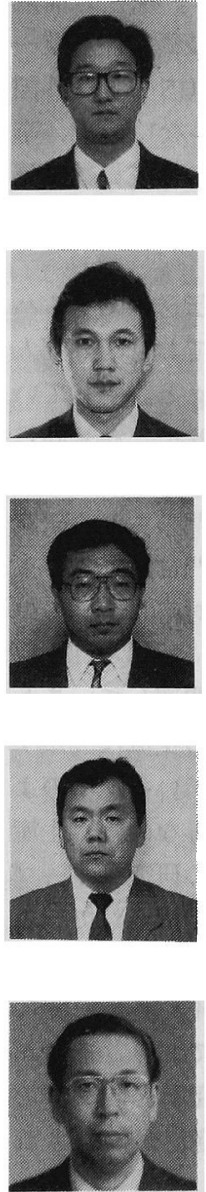

\section{佐 藤 仁 志（准員）}

昭和 42 年 1 月 28 日生。平成 3 年 3 月 東海大学卒業。同年 4 月同大学大学院修 士課程進学。

\section{Marzan Aziz Iskandar（正員）}

1958 年 5 月 18 日生。平成 3 年 3 月東 海大学大学院修士課程修了。同年 4 月同 大学大学院博士課程進学。

\section{的 場 誠 一 (非会員)}

昭和 31 年 6 月 23 日生。 54 年 3 月電 気通信大学卒業。同年 4 月(株)開発計算 センター入社。現在に至る。

\section{岡 部 孝継 (正員)}

昭和 38 年 7 月 14 日生。 63 年 3 月東 海大学大学院修士課程修了。同年 4 月電 源開発入社。現在に至る。

\section{水 谷 芳 史 (正員)}

昭和 19 年 2 月 18 日生。 43 年 3 月東 海大学大学院修士課程修了。61 年同大 学教授。工学博士。 